Journal of Applied Veterinary Sciences, 6 (1): 38 - 44 (2021).

ISSN: Online: 2090-3308, Print: 1687-4072

Journal homepage : https://javs.journals.ekb.eg

\title{
Trials For Preparation Of Combined Vaccine Of Equine Influenza, Equine Herpesvirus-1, Rabies Virus And Tetanus Toxoid
}

\author{
Safaa A. Warda ${ }^{1}$, Eman M. Ebied ${ }^{1}$, Nashwa K. Madkour ${ }^{1}$, Fatma F.Warda ${ }^{1}$, Omaima \\ A.E. El-Shamandy ${ }^{2}$, Wafaa R. Abdelaziz ${ }^{3^{*}}$, Hala EI Sawy ${ }^{4}$, Attyat M. Kotb ${ }^{2}$ \\ ${ }^{1}$ Department of Equine Vaccine Research, Veterinary Serum and Vaccine Research Institute (VSVRI), \\ Abbassia, Cairo, Agriculture Research Center (ARC), Egypt. \\ ${ }^{2}$ Department of Pet Animal Vaccine Research, Veterinary Serum and Vaccine Research Institute \\ (VSVRI), Abbassia, Cairo, Agriculture Research Center (ARC), Egypt. \\ ${ }^{3}$ Department of Sera and antigens Research, Veterinary Serum and Vaccine Research Institute (VSVRI), \\ Abbassia, Cairo, Agriculture Research Center (ARC), Egypt. \\ ${ }^{4}$ Department of Quality Control Lab., Veterinary Serum and Vaccine Research Institute (VSVRI), \\ Abbassia, Cairo, Agriculture Research Center (ARC), Egypt. \\ *Corresponding Author, Wafaa R. Abdelaziz, E-mail: dr.wafaa3@gmail.com
}

\begin{abstract}
A combined vaccine of Equine influenza (EI), equine herpesvirus-1 (EHV-1), rabies virus and tetanus toxoid adjuvanted with saponin and Alhydrogel was prepared. Quality control testing of such vaccine revealed that it was free from foreign contaminants, safe for Guinea-pigs, mice and mares. It was inoculated into Guinea -pigs as a preliminary evaluation for its potency and it was proven safe and potent. Also, it exceeded the permissible protective level allowed to be used for the vaccination of horses. Two groups of mares were used for evaluating the potency of the vaccine. The first one received two doses $(5 \mathrm{ml})$ of the prepared vaccine with 4 weeks interval while the $2^{\text {nd }}$ group was kept without vaccination as control. The mean haemagglutination inhibition (HI) influenza antibody titer reached its maximum at the $2^{\text {nd }}$ month post-vaccination (MPV); 2048 while EHV-1 antibodies reached the peak at the $3^{\text {rd }}$ MPV as recorded by ELISA and neutralizing indices; 1790 and 3.50. Rabies antibodies were detectable in vaccinated mares by the $2^{\text {nd }}$ week post-vaccination showing titers of 16 and 1.0 by serum neutralization test (SNT) and ELISA, respectively recording their peaks (128 by SNT and 2.15 by ELISA) at the $2^{\text {nd }}$ MPV. Tetanus antitoxic titer increased till reaching the peak at the $2^{\text {nd }}$ MPV (40IU/ml) as determined by toxin neutralization test. Depending on these results, it could be concluded that the prepared inactivated EI, EHV1 , rabies and tetanus vaccine is safe and potent for mares providing them with good protective levels of specific antibodies against the 4 used antigens up to 6 months.
\end{abstract}

Keywords: Equine influenza, herpesvirus-1, Rabies, tetanus, Vaccine.
Original Article:

DOI:https://dx.doi.org/10.21608/j avs.2021.140096

Received :07 Secember, 2020.

Accepted :15 January, 2021.

Published in January, 2021.

This is an open access article under the term of the Creative Commons Attribution 4.0 (CCBY) International License . To view a copy of this license, visit:

http://creativecommons.org/licenses/by/4.0/

J. Appl. Vet. Sci., 6(1): $38-44$.

\section{INTRODUCTION}

Equine influenza (EI) is a highly contagious viral respiratory disease characterized by fever, depression, mucoid or mucopurulent discharge and coughing which develop after a short incubation period. The disease spreads quickly through direct aerosol transmission or indirect as a consequence of inadequate hygienic precautions and the co-transport of infected and uninfected horses (Laabassi et al., 2015). The virus currently circulating in horses is H3N8 antigenic subtype (Cullinane and Newton, 2013) and (Gildea et al., 2016)
Equine herpes viruses (EHVs) belong to the Herpesviridae family. The family is subdivided into three subfamilies $(\alpha, \beta$ and $\gamma)$ based on tissue tropism, pathogenicity and behavior in tissue culture (Davison et al., 2002). Both EHV1 and 4 are economically important and affect the respiratory tracts of horses worldwide (Allen and Bryans, 1986). EHV-1 is an alpha herpes virus that causes a broad range of manifestations in horses, including a central nervous system disease that includes spinal cord and brain disorders (myeloencephalopathy), respiratory disease, abortions, perinatal death and chorioretinopathy 
(Mesquita et al., 2017). Some vaccines are available but their efficacies remain limited (Khusro et al., 2020).

Rabies is a zoonotic disease that affects the Central Nervous System (CNS) and causes acute and fatal encephalitis in the affected hosts. The etiologic agent of the disease is rabies virus; a neurotropic, RNA virus of the order Mononegavirales, family Rhabdoviridae genus Lyssavirus. The rabies infection is mainly transmitted when infected saliva reaches nervous tissue through a bite wound or skin injuries, or breached mucous membranes. Once clinical symptoms appear, it is almost $100 \%$ fatal (WHO, 2018).

Today, rabies vaccines which are used for both humans and animals as recommended by the World Health Organization are made of inactivated viruses produced in continuous cell lines (WHO, 2018) Tetanus is a highly fatal bacterial infectious disease caused by an anaerobic spore-forming bacterium; Clostridium tetani. This disease is prevalent globally and affects all types of domestic animals (Brüggemann et al., 2003). Horses are the most susceptible of all domestic animals, representing more than $80 \%$ of affected hosts. Infection occurs due to its spore as it enters the body via any wounds especially deep lacerated wounds caused by sharp objects or internal wounds. Vaccination is effective, practical and give long-term protection by using the tetanus toxoid which is the most effective prophylactic immunogene today. Regular vaccination of all horses against tetanus is essential (paillot et al., 2017).

The protection induced by first generations of whole inactivated, aluminum hydroxide adjuvanted EI vaccine primarily relied on stimulation of high antibody levels. It is known that Aluminum hydroxide triggers a Th2, antibody -orientated immune response (Lindblad, 2004 and Dalia, 2017). Saponin based adjuvants can modulate the cell mediated immune system as well as enhance antibody production and have the advantage that only a low dose is needed for adjuvant activity ( Rajput et al., 2007 and Abdelhady, 2016). Vaccine formulation that enables a reduction in the number of different vaccinations required each year will provide protection from the most critical pathogens as a combined vaccine against Equine influenza and EHV-1 in horses is highly desirable (Nashwa et al., 2016).

The combined inactivated vaccine (EIV, EHV1 and Tetanus Toxoid (TT) adjuvanted with saponin and Alhydrogel was evaluated in guinea pigs and horses. The results obtained were proved it to be safe, potent and stable at $4^{\circ} \mathrm{Cfor}$ up to 12 months (Bayoumi et al., 2018a)
Thus, the present study was planned to assess the immune response of horses to a combined inactivated EI, EHV-1, rabies and TT vaccine adjuvanted with saponin and Alhydrogel.

\section{MATERIALS AND METHODS}

\section{Strains used for vaccine preparations}

- A locally identified freeze-dried equine influenza virus (A/equi-2/Egypt /6066 NAMRU3VSVRI/2008) egg passage three (EP3) (Magda et al., 2011) and locally isolated freeze dried EHV-1 (EHV-1/Egypt/ VSVRI/Zahraa /2014)at its VERO cell passage two $\left(\mathrm{VEp}_{2}\right)$ were supplied by the Department of Equine Vaccine Research (DEVR), Veterinary serum and vaccine Researches Institute (VSVRI), Abbasia, Cairo, Egypt

- Tissue culture adapted Evelyn Rokitnicki Abelseth (ERA) rabies virus strain (with a titer of $10^{8.5}$ $\mathrm{TCID}_{50} / \mathrm{ml}$ ) was kindly supplied in a lyophilized form by WHO Collaborating Center for References and Researches in rabies Pasteur, Paris-France

- Lyophilized C. tetani strain (Harvard strain, 49805) obtained from Antigen and Sera Department, VSVRI, Abbassia, Cairo, Egypt.

These strains were used for preparation of an inactivated combined vaccine against equine influenza, equine herpes virus -1 , rabies virus and TT.

\section{Vaccine preparation}

The vaccine was prepared according to (Bayoumi et al., 2018a). An equal volume of inactivated of EIV and EHV-1 fluids and TT were mixed with inactivated rabies virus(Edries et al., 2017) then adjuvanted with $20 \%$ alhydrogel with saponin and dispensed in vials (five $\mathrm{ml}$ per vial). Each horse dose of inactivated combined vaccine contains $11 \log _{2}$ HA units of EIV and $8.5 \log _{10} \mathrm{TCID}_{50} / \mathrm{ml}$ of EHV-1, inactivated rabies virus $7.5-8 \log _{10} \mathrm{TCID}_{50} / \mathrm{ml}$ and tetanus toxoid 40 limits of flocculation $(\mathrm{Lf} / \mathrm{ml})$ (Heldens et al., 2010 and Soliman et al., 2011).

\section{Experimental animals}

3.1.Mares

Ten apparently healthy adult mares (2-4 years old) were used in the present study with 4 pregnant mares to test the safety and 3 mares were used to assess the potency of the prepared vaccine while last 3 mares were kept unvaccinated as control animals. All mares were housed under hygienic measures receiving balanced ration and adequate water according to animal ethics.

\subsection{Mice}

Four pregnant Swiss Albino mice of 4-6 weeks old were used for safety testing of inactivated EHV-1 as a component of the prepared vaccine. About 60 mice were used in the toxin neutralization test for evaluating the potency of tetanus antitoxin. 


\subsection{Guinea pigs}

Fifteen seronegative Guinea pigs of about 300$400 \mathrm{gm}$ body weight were divided equally into three groups; the first group was used to assess the safety of the prepared TT, the second group was used for assessing the potency of the prepared vaccine and the $3^{\text {rd }}$ group was kept without inoculation as control group.

\section{Vaccine quality control 4.1.Sterility}

This test was performed on each inactivated virus fluid before mixing as well as on the final product. Samples from them were cultured on different media to exclude bacterial, fungal, mycoplasma contaminations. (OIE, 2019a).

\subsection{Safety}

\subsubsection{Residual infective virus activity}

This test was performed on the inactivated virus fluid immediately after inactivation process to ensure complete virus inactivation as follow:

a) Undiluted inactivated EIV was inoculated into the allantoic cavity of a group of specific pathogen free (SPF) Embryonated Chicken Egg (ECE) 9-11 day old and haemagglutinating activity should not be detected (OIE, 2019b).

b) Undiluted inactivated EHV-1 was inoculated on both VERO and Chorioallantoic Membrane (CAM) of embryonated chicken eggs 11-13 days (Safaa and Hussein, 2012) revealing no CPE in the cell culture and no lesions in CAM.

c) Undiluted inactivated ERA rabies virus was inoculated in both BHK cell culture and in weaned albino Swiss mice with no CPE in BHK cells and no symptoms in mice ( OIE, 2018)

d) Five ml of TT were injected subcutaneously as two equally divided doses at separate sites into each of five Guinea-pigs, each weighing 350-400 g. No significant local or systemic reaction is produced. The Guinea-pigs were observed for 21 days. No Guinea-pig showed signs of tetanus or died from it (British pharmacopoeia, 2009)

\subsubsection{Animals safety test} as follow:

It was performed on the final vaccine product

a) Four pregnant mares in the last trimester of pregnancy were inoculated $\mathrm{I} / \mathrm{M}$ with $5 \mathrm{ml}$ of the prepared vaccine (OIE, 2019b) and observed for two weeks.

b) Four pregnant mice were inoculated subcutaneously (S/C) with $0.2 \mathrm{ml}$ of the prepared vaccine (Slater $\boldsymbol{e t}$. Al., 1993).

All groups of both mares and mice were kept under observation for two weeks in good hygienic conditions. c) Five Guinea pigs were injected with $5 \mathrm{ml}$ of the vaccine $\mathrm{S} / \mathrm{C}$ as 2 equally divided doses, at separate sites and kept under observation in a good hygienic condition for 21 days to evaluate the safety of tetanus toxoid in the vaccine. (British Pharmacopoeia, 2009).

\subsection{Potency of the prepared vaccine In Guinea pigs}

Ten seronegative Guinea pigs (G. pigs) were divided into 2 groups (5 G. pigs/group). Group (A) was inoculated subcutaneously $(\mathrm{S} / \mathrm{C})$ with $5 \mathrm{ml}$ of prepared vaccine; group (B) was kept as a control under the same conditions of the experiments. Twenty one days post inoculation, serum samples were collected from both groups and tested for $\mathrm{HI}$ antibody titer using $\mathrm{HI}$ assay for EI virus (OIE, 2019b). Twenty one days post inoculation, group A received a booster dose of the vaccine then 14 days later, serum samples were collected and tested for EHV-1 antibodies using ELISA (Guo et.al., 1989), rabies antibodies using SNT and ELISA (OIE, 2018) and tetanus antitoxin titer using toxin neutralization test (TN) (British Pharmacopoeia, 2009)

\section{In horses}

Six local mares, two - four years old, seronegative for rabies and tetanus or with low antibodies titer against EIV\&EHV-1 were divided into 2 groups. Group (A) was vaccinated with two doses of the prepared vaccines one month apart using a dose of $5 \mathrm{ml}$ andgroup (B) was kept as a control group under the same conditions of the experiments. Serum samples were collected from each group every two weeks for two months then monthly until the $7^{\text {th }}$ months post vaccination for monitoring the immune response using $\mathrm{HI}$ test for EI virus, neutralization indices and ELISA for EHV-1, SNT and ELISA for rabies and TN test for tetanus antitoxin titer.

\section{Serological examination}

5.1.Haemagglutination test (HA) and HaemagglutinationInhibition test (HI)

They were performed according to the method described by (OIE, 2019b) for measuring the equine influenza virus titer and antibody response.

5.2.Enzyme linked immunosorbent assay (Solid phase ELISA) (Single-dilution) was carried out according to (SuGiura et al.,1997) and neutralization indices according to (Shankar and Yadav, 1986) and (Abdelhady, 2016) for measuring the EHV-1 antibodies.

\subsection{Serum neutralization test (SNT) and ELISA for monitoring of rabies antibodies}

SNT was carried out using the microtiter technique according to (Rossiter et al., 1985) and the rabies serum neutralizing antibodies titer was calculated by the method of (Singh et al., 1967). 
Zhenrui Rabies virus Antibody Quantitative ELISA kit, version RBV1805003 was supplied by Shenzhen Zhenrui Biotech Co., Ltd. China and the rabies antibody titer was expressed as IU/ml according to the standard curve performed by the kit manufacturer.

\subsection{Toxin neutralization test for monitoring of tetanus antitoxin titer}

The antitoxin titer was measured by mice TN which was done according to (Martha and Craig, 1997).

Ethical approval: Institutional Animal Care and use committee at veterinary serum and vaccine research institute hereby acknowledge the research manuscript and it has been reviewed under its research authority.

\section{RESULTS}

Concerning the safety of the prepared vaccine, it was found that there are no residual virulent viruses in the inactivated viral fluids as proved by absence of haemagglutinating activity for EIV, pock lesion and CPE in both CAM and VERO cells for EHV-1 respectively. No CPE of rabies virus in BHK cells and no rabies signs in mice as recommended by OIE (2018 and 2019b).Also, there was no signs of tetanus in guinea pigs. Also, all inoculated horses showed normal body temperature and no undesirable local or systemic reaction observed following primary and booster injections. There is no abortion in pregnant mares.

Testing the potency of the prepared vaccine in G. pigs; the demonstrated data in table (1) showed that G. pigs serum samples of group (A) exhibited Equine Influenza antibodies with mean HI titer 1843.2 by the $3^{\text {rd }}$ WPIwhile, EHV-1 elicited an obvious seroconversion in Guinea pigs; serum neutralizing antibodies were detectable (550) twenty one days after the primary inoculation and a marked increase in the titer of virus neutralizing antibodies was obtained by 2 weeks post second dose (about 2 fold increase; 1250). Tetanus antitoxin titer was $40 \mathrm{IU} / \mathrm{ml}$ by the $2^{\text {nd }}$ week post second inoculation.

Table 1: Mean antibody titers in sera of Guinea pigs inoculated with the prepared vaccine.

\begin{tabular}{|c|c|c|c|c|}
\hline \multirow{2}{*}{$\begin{array}{c}\text { Applied } \\
\text { test }\end{array}$} & \multicolumn{3}{|c|}{ Group-A } & \multirow[t]{2}{*}{ Group-B } \\
\hline & $\begin{array}{c}\text { Pre- } \\
\text { vaccination }\end{array}$ & *3WPI & $* 2 \mathrm{WPB}$ & \\
\hline EI-HI & - & 1843.2 & - & 0 \\
\hline $\begin{array}{l}\text { HV-1 } \\
\text { EHV-1 }\end{array}$ & - & 550 & 1250 & 0 \\
\hline TT(TN) & - & 20 & 40 & 0 \\
\hline
\end{tabular}

Group A: was vaccinated with $(5 \mathrm{ml})$ of prepared vaccine.

Group B: was kept without vaccination.

*WPI: Weeks post-inoculation.

*WPB: Weeks post boostering.
Regarding the immunogenicity of the prepared vaccine in mares, the demonstrated data in table (2) show that EIV antibodies determined by HI test were detectable at 2 weeks post inoculation with a mean titer 256 , which at 4 weeks reached 128. Such antibodies reached their maximum titer at 2 months post vaccination (MPV) to be 2048, then began to decline gradually till the $6^{\text {th }}$ month.

Table 2: EI- HI antibodies titer in sera of mares inoculated with the prepared vaccine

\begin{tabular}{|c|c|c|}
\hline \multirow{2}{*}{$\begin{array}{c}\text { Periods post- } \\
\text { vaccination }\end{array}$} & \multicolumn{2}{|c|}{$\begin{array}{c}\text { EI-HI antibody titer/ } \\
\text { WPV }\end{array}$} \\
\cline { 2 - 2 } & Group-A & Group-B \\
\hline 0 time & 8 & \multirow{2}{*}{$\leq 4$} \\
\hline $2 \mathrm{WPV}$ & 256 & \multirow{2}{*}{$\leq 4$} \\
\hline $4 \mathrm{WPV}$ & 128 & \\
\hline \multicolumn{2}{|c|}{ Boostering } & \\
\hline 6WPV & 1024 & \multirow{2}{*}{} \\
\hline $2 \mathrm{MPV} * *$ & 2048 & \\
\hline $3 \mathrm{MPV}$ & 2048 & \\
\hline 4MPV & 1024 & \\
\hline 5MPV & 512 & \\
\hline 6MPV & 512 & \\
\hline $7 \mathrm{MPV}$ & 128 & \\
\hline
\end{tabular}

Group A: was vaccinated with (5ml) of prepared vaccine. Group B: was kept without vaccination.

* WPV: Weeks post vaccination.

** MPV: Months post-vaccination.

Results in table (3) indicates that EHV-1 antibodies were detectable (656) at 2WPV with mean ELISA titer and neutralizing index (0.60) for group(A) and reached its maximum titer at $3{ }^{\text {rd }} \mathrm{MPV}$ with mean ELISA titer (1790) and neutralizing index (3.50).

Table 3: Mean ELISA and VNT titers of EHV-1 antibodies in horses vaccinated with the prepared vaccine.

\begin{tabular}{|c|c|c|c|c|}
\hline \multirow{2}{*}{$\begin{array}{l}\text { Periods post- } \\
\text { vaccination }\end{array}$} & \multicolumn{2}{|c|}{ Group-A } & \multicolumn{2}{|c|}{ Group-B } \\
\hline & ELISA & $\mathrm{NI}$ & ELISA & NI \\
\hline 0 time & 95 & 0.20 & 98 & 0.20 \\
\hline $2 \mathrm{WPV} *$ & 656 & 0.60 & 90 & 0.20 \\
\hline 4WPV & 420 & 0.60 & 92 & 0.20 \\
\hline \multicolumn{5}{|c|}{ Bootstring } \\
\hline $6 \mathrm{WPV}$ & 1390 & 2.60 & 95 & 0.20 \\
\hline $2 \mathrm{MPV} * *$ & 1530 & 3.50 & 92 & 0.20 \\
\hline $3 \mathrm{MPV}$ & 1790 & 3.50 & 92 & 0.20 \\
\hline 4MPV & 1680 & 3.50 & 92 & 0.20 \\
\hline $5 \mathrm{MPV}$ & 1430 & 2.80 & 92 & 0.20 \\
\hline $6 \mathrm{MPV}$ & 1100 & 1.60 & 92 & 0.20 \\
\hline 7MPV & 910 & 1.40 & 92 & 0.20 \\
\hline
\end{tabular}

Group A: was vaccinated with (5ml) of prepared vaccine. Group B: was kept without vaccination.

*WPV: Weeks post vaccination.

**MPV: Months post- vaccination. 
Table (4) demonstrates that rabies antibodies were detectable in vaccinated mares by the $2^{\text {nd }}$ week post vaccination showing titers of 16 and 1.0 by SNT and ELISA respectively recording their peaks 128 by SNT and 2.15 by ELISA by the second month.

Table 4: Rabies serum ELISA and neutralizing antibody titer in vaccinated mares with the prepared vaccine

\begin{tabular}{|ccccc|}
\hline $\begin{array}{c}\text { Periods } \\
\text { post- } \\
\text { vaccinatio } \\
\mathrm{n}\end{array}$ & \multicolumn{2}{c}{ Group-A } & \multicolumn{2}{c|}{ Group-B } \\
\cline { 2 - 5 } & ELISA & $\begin{array}{c}\text { SNT } \\
\text { titer* }\end{array}$ & $\begin{array}{c}\text { ELIS } \\
\mathrm{A}\end{array}$ & $\begin{array}{c}\text { SNT } \\
\text { titer }\end{array}$ \\
\hline 0 time & 0.01 & 0 & 0.01 & 0 \\
\hline $2 \mathrm{WPV}^{*} *$ & 1.0 & 16 & 0.01 & 0 \\
\hline $4 \mathrm{WPV}$ & 1.2 & 32 & 0.10 & 0 \\
\hline \multicolumn{4}{c}{ Bootstring } \\
\hline 6WPV & 1.35 & 64 & 0.01 & 0 \\
\hline 2MPV*** & 2.15 & 128 & 0.01 & 0 \\
\hline $3 \mathrm{MPV}$ & 2.15 & 128 & 0.01 & 0 \\
\hline 4MPV & 2.13 & 128 & 0.01 & 0 \\
\hline 5MPV & 2.13 & 128 & 0.01 & 0 \\
\hline $6 \mathrm{MPV}$ & 2.11 & 128 & 0.01 & 0 \\
\hline 7MPV & 2.10 & 128 & 0.01 & 0 \\
\hline
\end{tabular}

Group A: was vaccinated with $(5 \mathrm{ml})$ of prepared vaccine. Group B: was kept without vaccination.

**WPV: Weeks post-vaccination.

***MPV: Months post-vaccination.

*Rabies serum neutralizing antibody titer= the reciprocal of the final serum dilution which neutralized and inhibited the $\mathrm{CPE}$ of $100 \mathrm{TCID}_{50}$ of rabies virus.

ELISA results were expressed as IU/ml where the protective value should not be less than $0.5 \mathrm{IU} / \mathrm{ml}$.

Regarding the tetanus toxoid component in the combined vaccine, table (5) showed that the antitoxins were detected in vaccinated animals at the $2^{\text {nd }}$ week postvaccination $(12 \mathrm{IU})$ reached their peak by the $2^{\text {nd }}$ $\operatorname{MPV}(40$ IU) then declined till the end of the experiment(2 IU).

Table 5: Tetanus antitoxin titer in sera of mares vaccinated with the prepared vaccine tested by TN test

\begin{tabular}{|c|c|c|}
\hline \multirow{2}{*}{$\begin{array}{l}\text { Periods post- } \\
\text { vaccination }\end{array}$} & \multicolumn{2}{|c|}{ Tetanus antitoxin (IU/ml) } \\
\hline & Group-A & Group-B \\
\hline 0 time & $<0.01$ & \multirow{3}{*}{$<0.01$} \\
\hline $2 \mathrm{WPV} *$ & 12 & \\
\hline 4WPV & 25 & \\
\hline \multicolumn{3}{|c|}{ Bootstring } \\
\hline $6 \mathrm{WPV}$ & 30 & \multirow{7}{*}{$<0.01$} \\
\hline $2 \mathrm{MPV} * *$ & 40 & \\
\hline $3 \mathrm{MPV}$ & 30 & \\
\hline 4MPV & 20 & \\
\hline $5 \mathrm{MPV}$ & 10 & \\
\hline 6MPV & 5 & \\
\hline 7MPV & 2 & \\
\hline
\end{tabular}

Group (A): was vaccinated with $5 \mathrm{ml}$ of the prepared vaccine. Group (B): was kept without vaccination as a control at the same conditions of the experiment.

*WPV: Weeks post-vaccination

**MPV: Months post-vaccination

\section{DISCUSSION}

Horses are commonly vaccinated to be protected against pathogens which are endemic within the general horse population, such as EIV and EHV-1, and against a variety of diseases which are less common but lead to greater morbidity and mortality, such as tetanus (Ribeiro et al., 2018) and rabies (Schwarz et al., 2020). Recent equine vaccines trials have indicated that the efficacy of vaccines is unaffected by their administration as monovalent or polyvalent formulations (Heldens et al., 2002). So, this study was developed to evaluate the immune response of equines to combined vaccine of inactivated equine influenza virus, equine herpes virus-1, rabies virus and tetanus toxoid.

The vaccine was inoculated in guinea pig as a preliminary evaluation for its potency. As seen in table (1), the Equine Influenza HI antibodies recorded exceeds the protective level (64) that reported by (OIE, 2019). As for Herpes virus-1 antibodies the results came in agreement with those of (Guo et al., 1989) and (Nashwa et al., 2016) who mentioned that there was more than 2 fold increase after the second dose. Tetanus antitoxic titer reached $40 \mathrm{IU} / \mathrm{ml}$ by the second week post second dose and this titer exceeds the requirements of British Pharmacopoeia (2009); as it requires a minimum of $30 \mathrm{IU} / \mathrm{ml}$ in Guinea pig for tetanus toxoid to be adequate in vaccination of horses.

Regarding the immunogenicity of the prepared vaccine in mares, the elicited $\mathrm{HI}$ antibodies against equine influenza exceeds the requirements of OIE (OIE, 2019b) who reported that the protective EI-HI antibody titer should not be less than 64 .

Table (3) showed the immune response against herpes virus-1, the results indicate more than fourfold increase in antibody titer against the virus and this agree with those of (Bannai et al., 2014) and (Rusli $\boldsymbol{e t}$ al., 2014) who found that ELISA antibodies began to increase by day 14 post injection then reached its peak at 2 months with 4-fold increasing, which indicated good immune response.

As shown in table (4) rabies antibodies values indicated that the tested vaccine is potent for mares where similar results were obtained by Khodeir, (1999); Khodeir and Daoud, (2008); Albehwar, (2009) and Eiaka, (2017) using cell culture inactivated rabies vaccine adjuvant with aluminum hydroxide gel and recommended that the protective level of rabies serum neutralizing antibodies should not be less than 16 by SNT and 1.0 by ELISA.

Regarding tetanus antitoxic titer, the titer reached $2 \mathrm{IU} / \mathrm{ml}$ at the $7^{\text {th }}$ month, which could be 
accepted as protective level of tetanus antitoxin titer in animal sera, as measured by $\mathrm{TN}$ as it is recommended that it must be at least $0.01 \mathrm{IU} / \mathrm{ml}$ as there are indications that this is the actual protective level (Gupta et al., 1985).

These results agree with those obtained by (Heldens et al., 2001) who indicated that a combined vaccine against EI, EHV-1 and tetanus is immunogenic and confer immunity for up to 6 months post vaccination. From the above result it is clear that after the $6^{\text {th }}$ month revaccination with combined EIV,EHV-1 and tetanus vaccine is required as stated by (Bayuomi et al., 2018b) who pointed out that the third dose developed high antibodies titer above the required level for clinical protection against influenza and tetanus until 12 months and 6 months for EHV-1. Thus, alternative additional inactivated EHV-1 should be used.

\section{CONCLUSION}

The present obtained results indicate that there is no antagonizing effect of the used vaccine components on the immune response of vaccinated animals and accordingly it can be conclude that the combined vaccine is safe and immunogenic using a vaccination scheme consisting of 2 doses with one month apart followed by a third vaccination at $6^{\text {th }} \mathrm{MPV}$ to maintain a maximal protection against equine influenza, Herpesvirus-1, Rabies and tetanus infections.

\section{REFERENCES}

ABDELHADY, H. A. 2016. Preparation of inactivated EHV-1 with different adjuvants. Ph.D. Thesis; Immunology, Fac. Vet. Med. Alexandria Univ.

ALBEHWAR, A.M. 2009. Studies on prophylactic and emergency vaccination of farm animals against rabies; Ph. D. Thesis (Infectious Diseases) Fac. Vet. Med. Cairo Univ.

ALLEN, G.P. AND BRYANS, J.T. 1986. Molecular epidemiology, pathogenesis and prophylaxis of equine herpesvirus-1 infections.In: Progress in Veterinary Microbiology and Immunology, Vol. 2, Pandey R., ed. Karger, Basel, Switzerland \& New York, USA, 78-144.

BANNAI, H., MAE, N., ODE, H. ET AL. 2014. Successful control of winter pyrexias caused by equine herpesvirus type 1 in Japanese training centers by achieving high vaccination coverage. Clinical and Vaccine Immunology, 21(8), 1070-1076.

BAYUMI, M., MOUSTAFA, A., MADKOUR, N., SELIM, A. AND ABDELAZIZ, W. 2018a. Trial for Preparation of Combined Equine Influenza virus, Equine Herpesvirus-1 and Tetanus Toxoid Vaccine. Benha Veterinary Medical Journal, 34(1), 106-116.

BAYOUMI, M., SELIM, A., MOUSTAFA, A. M., MADKOUR, N. K. AND EL-HELW, H. A. 2018b. Field Evaluation of the prepared combined equine influenza, equine herpesvirus-1 and tetanus toxoid vaccine in horses. Benha Veterinary Medical Journal, 34(1), 289-299.

BRITISH VET. PHARMACOPOEIA (EDS) 2009 Clostridium tetani vaccines (Veterinary Suppl.), p. 233 ISBN: 9780113227990.

BRÜGGEMANN, H., BÄUMER, S., FRICKE, W. F. ET AL. 2003. The genome sequence of Clostridium tetani, the causative agent of tetanus disease. Proceedings of the National Academy of Sciences, 100(3), 1316-1321.

CULLINANE, A. AND NEWTON, J. R. 2013. Equine influenza- $\mathrm{a}$ global perspective. Veterinary Microbiology, 167(1-2), 205-214.

DALIA, H.N. 2017. Study the effect of different adjuvants on inactivated equine herpes virus -1 vaccine. M.Sc. Virology, Fac. Science, Azher. Uni.

DAVISON, A.J. 2002. Evolution of the herpesviruses. Vet Microbiol 86:69-88

EDRIES, S. M., AMANI, A. S., ALbEHWAR, A. M., \& HEMMET, E. S. S. 2017. Improvement of inactivated rabies vaccine using montanide pet gelA. Benha J. Appl. Sci.(BJAS), 2(1), 145-149.

EIAKA, A.M.E. 2017. Virological and immunological studies on the effect of bee venom on rabies virus. $\mathrm{Ph}$. D. Thesis (Virology) Fac. Vet. Med. Benha Univ.

GILDEA, S., SANCHEZ HIGGINS, M. J., JOHNSON, G., WALSH, C. AND CULLINANE, A. 2016. Concurrent vaccination against equine influenza and equine herpesvirus-a practical approach. Influenza and other respiratory viruses, 10(5), 433-437.

GUO, P., GOEBEL, S., DAVIS, S. ET AL. 1989. Expression in recombinant vaccinia virus of the equine herpesvirus 1 gene encoding glycoprotein gpl3 and protection of immunized animals. Journal of Virology 63, 4189-4198.

GUPTA, R.K., MAHESHWARI, S. C. AND SINGH, H. 1985. The titration of tetanus antitoxin IV.Studies on the sensitivity and reproducibility of the toxin neutralization test. Journal of Biological Standardization, 13, 143-149.

HELDENS, J.G., KERSTEN, A.J., WESTSTRATE, M.W. AND VAN DEN HOVEN, R. 2001. Duration of immunity induced by an adjuvanted and inactivated equine influenza, tetanus and equine herpesvirus 1 and 4 combination vaccine. Vet Q. ;23(4):210-7.

HELDENS, J.G., VAN DE WOUW, J.C.A. AND VAN LOON, A.A.W. 2002. An updated equine influenza vaccine and an equine influenza herpesvirus combinationvaccine containing an Immunostimulant adjuvant provoke equal young foals throughout the primary vaccination course. Vet. J. 164, 288-291.

HELDENS, J.G., POUWELS, H.G., DERKS, C.G., VANDEZANDE, S.M. AND HOEIJMAKERS, M.J. 2010. Duration of immunity induced by an equine influenza and tetanus combination vaccine formulation adjuvanted with ISCOH-Matrix. Vaccine. 8: 28 (43): 6989-96.

KHODIER, M.H. 1999. Studies on vaccination of farm animals (cattle, horse, sheep) in addition to dogs and cats with inactivated tissue culture rabies vaccine; Beni-Suif Vet.Med.J.;9 (3-A): 111-120. 
KHODEIR, M. H. AND DAOUD, A.M. 2008. Preparation of anti-rabies hyperimmune serum for emergency Immunization of farm animals; $4^{\text {th }}$ Int. Sci. Conf. NRC, 1-9.

KHUSRO, A., AARTI, C., RIVAS-CACERES, R. ET AL. 2020. Equine herpesvirus-I infection in horses: Recent updates on its pathogenicity, vaccination, and preventive management strategies. Journal of Equine Veterinary Science, 87, 102923. https://doi.org/10.1016/j.jevs.2020.102923

LAABASSI, F., LECOUTURIER, F., AMELOT, G. ET AL. 2015. Epidemiology and genetic characterization of $\mathrm{H} 3 \mathrm{~N} 8$ equine influenza virus responsible for clinical disease in Algeria in 2011.Transbound.Emerg. Dis. 62, 623-631. http://dx.doi.org/10.1111/tbed.12209.

LINDBLAD, E.B. 2004. Aluminum adjuvantsin retrospect and prospectVaccine, 22, 3658-3668.

MAGDA, A. K., EMAN, M.E., NASHWA, K.M. ET AL. 2011. Characterization of Equine Influenza virus H3N8 isolated in Egypt in 2008' Apologia (3):35-44.

MARTHA, L.L. AND CRAIG, J.P. 1997. Clostridium tetani: immune response and diagnostic methods, In Manual of clinical laboratory immunology, Fifth edition, ASM press, Washington, D.C.

MESQUITA, A.L.P., ANDRESSA, F.A., DENNIS, A. ET AL.2017. Equine herpesvirus type 1 induces both neurological and respiratory disease in Syrian hamsters. Vet. Microbiol., 203,117-124

NASHWA, K.M., EMAN, M.E., NEHAL, S.S., FATMA, F.Y., EL-KABBANY, M.M.A. AND SOLIMAN, I.M.A. 2016. Duration of immunity induced by combined vaccine against Equine influenza and Equine herpesvirus-1. VMJG, 62, 1110-1423.

OIE TERRESTRIAL MANUAL, 2018. Rabies (infection with rabies virus and other lyssaviruses). Chapter 3.1.17.578-612.

OIE TERRESTRIAL MANUAL, 2019a. Tests for sterility and freedom from contamination of biological materials. Chapter 1.1.9.

OIE TERRESTRIAL MANUAL, 2019b. Equine Influenza (Infection with equine influenza virus). Chapter 3.5.7, 1-19.

PAILlOT, R., MARCILLAUD, PITEL, C., D'ABLON, X., PRONOST,,S. 2017. Equine Vaccines: How, When and Why? Report of the Vaccinology Session, French Equine Veterinarians Association, 2016, Reims.

RAJPUT, Z.I., HU, S.H., XIAO, C.W. AND ARIJO, A.G. 2007. Adjuvant effects of saponins on animal immune responses. J. Zhejiang Univ. Sci. B. 8, 153-161

REED, L.J. AND MEUNCH, H. 1938. A simple method of estimating fifty per cent endpoints. Am.J.Epidemiol. 27 (3):493-497.

RIBEIRO, M.G., NARDI JÚNIOR, G.D., MEGID, J. ET AL. 2018. Tetanus in horses: An overview of 70 cases. Pesquisa Veterinária Brasileira, 38(2), 285 293.

ROSSITER, P.B., JESSETT, D.M. AND TAYLOR, W.P. 1985. Microneutralization system for use with different strains of peste des petits ruminants and rinderpest virus. Tropical Animal Health and Production 17:75-81.
RUSLI, N.D., MAT, K.B. AND HARUN, H.C. 2014. A review: interactions of equine herpesvirus-1 with immune system and equine lymphocyte. Open J Vet. Med., 4, 294.

SAFAA, A.W. AND HUSSIN, M.G. 2012. Immune response of horsesvaccinated with tissue culture inactivated EHV - 1 oil Montanide ISA70 adjuvanted vaccine. Egypt J. Agric, Res; 90(3), 1309 - 1321.

SCHWARZ, D. G., BARRETO, F. M., BRANCO, M.D.A. ET AL. 2020. Equine Rabies in the Southern Region of Piauí State. Acta Scientiae Veterinariae, 48.

SHANKAR, H. AND YADAV, M. P. 1986. Occurrence of paralytic syndrome inequines due to equine Herpes virus - 1 Rev. Sci, Tech, Off. Int. Epiz., 5 (1): 15-21

SINGH, K. V., OSMAN, O.A., THANAA, I. BAZ AND IVON, EL- CICY.1967. The use of tissue culture rinderpest vaccine for Egyptian cattle and water buffaloes. Cornell. Vet. J., 7:465-479.

SLATER, I.D., GIBSON, J.S. AND FIELD, H.J. 1993. Pathogenicity of thymidine kinase - deficient mutant of EHV-1 in mice and specific pathogen free foals. J. Gen Virol., 74(5): 819-828.

SOLIMAN, I.M.A., EL-MENEISY, A.A., NASHWA, K.M. ET AL. 2011. Preparation of Combined Equine Influenza and Tetanus Toxoid vaccine. Veterinary Medical Journal Giza, 59, 353-363.

SUGIURA, T., KONDO, T., MATSUMURA, T. ET AL.1997. Evaluation of enzyme linked immunosorbent assay for titration of antibodies toEHV-1. J. Equine Sci., 8(3): 57-61.

WHO, 2018. Rabies vaccines and immunoglobulins: WHO position paper, April 2018. https://www.who.int/news-room/factsheets/detail/EA9FC951-9CFF-4913-8D5D95EE564F66B0

How to cite this article:

Safaa A. Warda, Eman M. Ebied, Nashwa K. Madkour, FatmaF.Warda, Omaima A.E. ElShamandy, Wafaa R. Abdelaziz, Hala El Sawy, and Attyat M. Kotb. 2021. Trials for Preparation of Combined Vaccine of Equine Influenza, Equine Herpesvirus-1, Rabies Virus and Tetanus Toxoid. Journal of Applied Veterinary Sciences, 6 (1): $38-44$. DOI:https://dx.doi.org/10.21608/javs.2021.140096 